\title{
The effect of dietary supplementation of salts of organic acid on production performance of laying hens
}

\author{
Ravinder Dahiya ${ }^{1}$, Raj Singh Berwal ${ }^{1}$, Sajjan Sihag ${ }^{1}$, Chandrashekhar Santosh Patil $^{2}$ and Lalit ${ }^{2}$
}

1. Department of Animal Nutrition, Lala Lajpat Rai University of Veterinary and Animal Sciences, Hisar, Haryana, India;

2. Department of Animal Genetics and Breeding, Lala Lajpat Rai University of Veterinary and Animal Sciences, Hisar, Haryana, India.

Corresponding author: Chandrashekhar Santosh Patil, e-mail: dr.cspatil03@gmail.com, RD: armaandahiya42@yahoo.com,RSB: rajberwal66@gmail.com, SS: sihagsajjan54@gmail.com, L: drlalit78@gmail.com

Received: 06-05-2016, Accepted: 28-11-2016, Published Online: 30-12-2016

doi: 10.14202/vetworld.2016.1478-1484 How to cite this article: Dahiya R, Berwal RS, Sihag S, Patil CS, Lalit (2016) The effect of dietary supplementation of salts of organic acid on production performance of laying hens, Veterinary World, 9(12): 1478-1484.

\begin{abstract}
Aim: An experiment was conducted to evaluate the effect of supplementing different levels of salts of organic acid in the laying hen's diet on their production performance and egg quality parameters during a period of 16-week.

Materials and Methods: A total of 140 white leghorn laying hens at 24 weeks of age were randomly distributed to seven dietary treatment groups, i.e. $\mathrm{T}_{1}$ (control), $\mathrm{T}_{2}(0.5 \%$ sodium-butyrate $), \mathrm{T}_{3}(1.0 \%$ sodium-butyrate $) \mathrm{T}_{4}(1.5 \%$ sodium-butyrate), $\mathrm{T}_{5}\left(0.5 \%\right.$ calcium-propionate), $\mathrm{T}_{6}(1.0 \%$ calcium-propionate $)$ and $\mathrm{T}_{7}(1.5 \%$ calcium-propionate $)$ consisting of 5 replications of 4 birds each in each treatment and housed in individual cages from 24 to 40 weeks of age. Feed intake, percent hen-day egg production, egg weight, egg mass production, feed conversion ratio (FCR), and economics of supplementation of salts of organic acids in layers' ration were evaluated.

Results: The dietary supplementation of salts of organic acids did not significantly affect the feed intake (g/day/hen) and body weight gain $(g)$. Different levels of supplementation significantly $(\mathrm{p}<0.05)$ improved production performance (percent hen-day egg production and egg mass production) as compared to control group. FCR in terms of feed intake (kg) per dozen eggs was lowest $(1.83 \pm 0.05)$ in $\mathrm{T}_{4}$ and feed intake $(\mathrm{kg})$ per $\mathrm{kg}$ egg mass was lowest $(2.87 \pm 0.05)$ in $\mathrm{T}_{5}$ as comparison to control $\left(\mathrm{T}_{1}\right)$ group. Salts of organic acids supplementation resulted in significant $(\mathrm{p}<0.05)$ improvement in FCR. Egg weight was significantly $(\mathrm{p}<0.05)$ increased at $0.5 \%$ level of salts of organic acids in the diet. The cumulative mean values of feed cost per dozen egg production were Rs. 44.14, 42.40, 42.85, 43.26, 42.57, 43.29 and 43.56 in treatment groups $\mathrm{T}_{1}, \mathrm{~T}_{2}, \mathrm{~T}_{3}$, $\mathrm{T}_{4}, \mathrm{~T}_{5}, \mathrm{~T}_{6}$ and $\mathrm{T}_{7}$, respectively, and reduction in feed cost per kg egg mass production for Rs. 0.52 and 0.99 in groups $\mathrm{T}_{2}$ and $\mathrm{T}_{5}$, respectively, in comparison to $\mathrm{T}_{1}$ group.
\end{abstract}

Conclusions: It can be concluded that supplementation of salts of organic acids may improve persistency of lay, egg weight, and FCR. From economical point of view, egg production was more profitable at $0.5 \%$ level of sodium butyrate and $0.5 \%$ level of calcium propionate which reduced the feed cost per dozen eggs and per kg egg mass production without affecting the egg quality.

Keywords: calcium-propionate, egg production, feed conversion ratio, feed intake, sodium butyrate and layers.

\section{Introduction}

The poultry industry is a well-organized and fast growing sector of Indian economy. India is emerging as the world's $2^{\text {nd }}$ largest poultry market with an annual growth of more than 14\%, producing 61 million tones or $3.6 \%$ of the global egg production and annual growth rate of egg production is 5-8\% [1].

Antibiotics have been widely used in poultry production for decades to improve growth rate and feed conversion efficiency; however, their use as growth promoters in the poultry industry has been intensively controversial because of the development of bacterial

Copyright: Dahiya, et al. Open Access. This article is distributed under the terms of the Creative Commons Attribution 4.0 International License (http://creativecommons.org/licenses/by/4.0/), which permits unrestricted use, distribution, and reproduction in any medium, provided you give appropriate credit to the original author(s) and the source, provide a link to the Creative Commons license, and indicate if changes were made. The Creative Commons Public Domain Dedication waiver (http://creativecommons.org/ publicdomain/zero/1.0/) applies to the data made available in this article, unless otherwise stated. resistance and potential consequences on the human health [2]. In response to this apparent threat, the European Commission (EC) decided to phase out, and ultimately ban (January $1^{\text {st }}, 2006$ ), the marketing and use of antibiotics as growth promoters in feed (EC Regulation No. 1831/2003). Now the poultry sector is continuously searching for new feed additives to improve the feed efficiency with minimum deleterious effects on animal health. Organic acids and their salts are generally regarded as safe and have been approved by most member states of European Union to be used as feed additives in the animal production [3]. Organic acid associated with specific antimicrobial activity are short chain acids $\left(\mathrm{C}_{1}-\mathrm{C}_{7}\right)$ which are widely distributed in nature as normal constituents of plants or animal tissues and also formed through microbial fermentation of carbohydrates predominantly in the ceca of poultry [4]. The advantage of salts over acids is that they are generally odorless and easier to handle in the feed manufacturing process owing to their solid 
and less volatile form [5]. Organic acids can serve as a meaningful tool to controlling all enteric nonpathogenic and pathogenic especially acid-intolerant bacteria such as Escherichia coli, Salmonella, and Campylobacter species [6]. Apart from the antimicrobial activity, they lower down the gastric $\mathrm{pH}$ which accelerates the conversion of pepsinogen to pepsin, which ultimately improves the absorption and digestibility of proteins, amino acids, minerals and serve as substrates in the intermediary metabolism.

Organic acids have made a great contribution to profitability in poultry production and also provided people with nutritious poultry products [7]. Nollet et al. [8] and Mahdavi et al. [9] reported that a positive effect of sodium butyrate and calcium propionate on laying performance that is conform the variable effect of the additives may be confounded by variations in gut flora and environmental conditions.

Therefore, this investigation was undertaken to study the effect of dietary supplementation of salts of organic acid on production performance in laying hens.

\section{Materials and Methods \\ Ethical approval}

All the experimental procedures have been conducted in accordance with the guidelines laid down by the Institutional Ethics Committee.

\section{Experiment and data structure}

The investigation was conducted at poultry farm, Department of Animal Genetics and Breeding, College of Veterinary sciences, LUVAS, Hisar. For this study, 140 single comb white leghorn laying hens at 24 weeks of age were randomly distributed to seven dietary treatment groups, i.e. $\mathrm{T}_{1}$ (control), $\mathrm{T}_{2}\left(0.5 \%\right.$ sodium-butyrate), $\mathrm{T}_{3}(1.0 \%$ sodium-butyrate) $\mathrm{T}_{4}(1.5 \%$ sodium-butyrate $), \mathrm{T}_{5}(0.5 \%$ calcium-propionate), $\mathrm{T}_{6}$ (1.0\% calcium-propionate) and $\mathrm{T}_{7}(1.5 \%$ calcium-propionate), consisting of five replications of four birds each in each treatment. Based on the proximate composition and metabolizable energy of feed ingredients the layer's control ration having maize grain as energy source was formulated as per BIS [10]. All the diets were analyzed for proximate principles [11] and were randomly divided into four groups. The hens were housed individually in cages. All the diets were prepared to be isocaloric and isonitrogenous. They were reared under identical conditions of environment and management of light, water, disease control, etc. Feed and water were supplied ad lib. The study was undertaken from 24 to 40 weeks of age of layers in the first phase of production cycle. The entire duration of the study was divided into eight periods of 14-day each.

For each replicate group, feed intake was measured on weekly basis, whereas egg production data were recorded daily. Random samples of 5 eggs from each treatment (1 egg/replicate) were collected at weekly intervals for measurement of egg weight and egg mass production. Feed conversion ratio (FCR) was expressed as kilogram of feed consumed per dozen egg produced and per $\mathrm{kg}$ of egg mass produced for the 8 periods $(24-26,26-28,28-30,30-32,32-34$, 34-36, 36-38 and 38-40 weeks of age) of 2 weeks each and cumulative intake of 1-8 periods (24-40 weeks). Average feed cost (Rs.) per dozen egg production and per $\mathrm{kg}$ egg mass production during progressive age (weeks) under different dietary treatments calculated at the end of study.

\section{Statistical analysis}

The statistical analysis of data was performed using SPSS 21.0 version of Microsoft [12]. Oneway ANOVA was used for the differences between groups. When the $p$ values were significant $(p<0.05)$, a Duncan's multiple range test was performed [13]. All the data were expressed as mean \pm standard errors.

\section{Results and Discussion}

The feed intake $(\mathrm{g}) / \mathrm{bird} / \mathrm{day}$, percent hen-day egg production, egg weight, egg mass production and FCR for 1-8 periods (24-40 weeks). The ingredient and chemical composition of basal diet fed to laying hens of control group have been given in Table-1. The contents of crude protein, crude fiber, ether extract, nitrogen-free extract, and organic matter of basal $\operatorname{diet}\left(\mathrm{T}_{1}\right)$ were $18.04 \%, 4.34 \%, 3.61 \%, 66.21 \%$ and

Table-1: The ingredients and chemical composition of control diet.

\begin{tabular}{lc}
\hline Ingredients & (kg/100 kg feed) \\
\hline Ingredient composition & 50 \\
Maize & 13 \\
Soybean meal & 7 \\
Groundnut cake & 12 \\
DORP & 5 \\
Rice polish & 6 \\
Fish meal & 3 \\
Mineral mixture & 1 \\
Salt & 3 \\
Shell grit & 100 \\
Total & $(\%$ DM basis $)$ \\
Nutrients & 18.10 \\
Chemical composition & 4.28 \\
CP & 3.65 \\
CF & 10.21 \\
EE & 89.79 \\
Ash & 63.76 \\
OM & 2697.17 \\
NFE & \\
ME* (Kcal/kg) & \\
\hline Spectromix - 10 g/quintal (Each g contained vitamin \\
A - 82,500 IU, vitamin D3 - 12,000 IU, vitamin \\
B2 - 50 mg, and vitamin K - 10 m) Spectrimix-BE - 10 g/q, \\
(Each g contained vitamin B1 - 80 mg, vitamin \\
B6-16 mg, niacin - 120 mg, vitamin B12 - 80 mg, \\
calcium pantothenate - 80 mg, vitamin E - 160 mg, \\
L-lysine HCl - 10 mg, DL methionine - 10 mg, and \\
calcium - 260 mg); (P < 0.01) **Calculated value [27]. \\
*Calculated kcal/kg. CP = Crude protein, CF = Crude \\
fiber, EE = Ether extract, NFE = Nitrogen-free extract, \\
OM = Organic matter, ME = Metabolizable energy, \\
DM = Dry matter, DORP = De Oiled Rice Polish \\
\end{tabular}


$92.20 \%$, respectively. The calculated value of ME was $2697.17 \mathrm{kcal} / \mathrm{kg}$ feed.

\section{Feed intake}

The results of the study revealed that the feed intake $(\mathrm{g} / \mathrm{hen} /$ day) was not significantly affected by the supplementation of different levels $(0.5 \%, 1.0 \%$, and $1.5 \%$ ) of salts of organic acids in the diet of layers (Table-2). These results are in agreement with Bonos et al. [14] and Kaya et al. [15] who reported that supplementation of salts of organic acids had no effect on average feed intake and body weight changes. By contrast, Youssef et al. [16] reported that supplementation of salts of organic acids significantly increased live body weight in layers.

\section{Percent hen-day egg production}

Percent hen-day egg production values were $74.72 \%, 76.16 \%, 77.39 \%, 79.14 \%, 75.70 \%, 76.72 \%$ and $77.77 \%$ in the treatment groups $\mathrm{T}_{1}, \mathrm{~T}_{2}, \mathrm{~T}_{3}, \mathrm{~T}_{4}, \mathrm{~T}_{5}$, $\mathrm{T}_{6}$ and $\mathrm{T}_{7}$, respectively (Table- 3 ). The results of the study unveiled that there was significant $(\mathrm{p}<0.05)$ positive effect on percent hen-day egg production by the supplementation of different levels $(0.5 \%, 1.0 \%$, and $1.5 \%$ ) of salts of organic acids in the diet of layers. Hen-day egg production was highest (79.14) in $\mathrm{T}_{4}(1.5 \%$ sodium butyrate) as compared to all other treatment groups. Similar trends of egg production were observed during different weeks of age of laying hens. The results are in close resemblance with Nollet et al. [8] reported a positive effect of sodium butyrate on laying performance increasing from $83.1 \%$ (control) to $83.8 \%, 84.3 \%, 84.8 \%$ and $86.1 \%(50,100,250$ and $500 \mathrm{ppm}$ of sodium butyrate supplementation), respectively. Moreover, Yesilbag and Colpan [17] observed that dietary supplementation of salts of organic acids had accelerated the laying capacity in 24-28 weeks old laying hens and extended the period of egg production in 36-38 weeks old hens than hens of control group.

\section{Egg weight}

The egg weight $(\mathrm{g})$ was highest (54.33) in $\mathrm{T}_{2}$ followed by $\mathrm{T}_{1}, \mathrm{~T}_{3}$ and $\mathrm{T}_{4}$ treatment groups (Table-3). This improvement in egg weight at $0.5 \%$ level might be due to lower percent hen-day egg production at $0.5 \%$ level which, consequently increased the weight of eggs because these two traits are negatively correlated [18]. Comparable results were found by Grashorn et al., 2012 [19] and Youssef et al. [16] depicted that egg weight was significantly improved by different dietary treatments as compared to control group (basal diet). In contrary to these findings, supplementation of salts of organic acids had no effect on average egg weight [20-22].

\section{Egg mass production}

The egg mass production was significantly $(p<0.05)$ increased in laying hens fed diets supplemented with different levels $(0.5 \%, 1.0 \%$, and $1.5 \%)$ of salts of organic acids as compared to laying hens fed control diet (Table-3). Egg mass production values in treatment groups $\mathrm{T}_{2}, \mathrm{~T}_{4}$ and $\mathrm{T}_{5}$ were significantly $(\mathrm{p}<0.05)$ higher from $\mathrm{T}_{1}, \mathrm{~T}_{3}, \mathrm{~T}_{6}$ and $\mathrm{T}_{7}$ treatment groups but did not show significant difference among themselves. Similar observations were also made by Soltan [23] and Attia et al. [24] who observed that egg mass was significantly improved due to increased egg production in layers. By contrary to these findings, no significant difference in egg mass production among different dietary treatments [25].

\section{FCR}

Results of the study revealed that feed intake per dozen egg production was significantly $(p<0.05)$ higher in control $\left(T_{1}\right)$ group as compared to other treatment groups $\left(\mathrm{T}_{2}, \mathrm{~T}_{3}, \mathrm{~T}_{4}, \mathrm{~T}_{5}, \mathrm{~T}_{6}\right.$ and $\left.\mathrm{T}_{7}\right)$. The mean value of feed intake per dozen egg production was lowest $(1.83 \pm 0.05 \mathrm{~kg})$ in $\mathrm{T}_{4}$ and differed significantly $(\mathrm{p}<0.05)$ from $\mathrm{T}_{1}, \mathrm{~T}_{2}, \mathrm{~T}_{5}$ and $\mathrm{T}_{6}$ groups, but did not differ statistically from $\mathrm{T}_{3}$ and $\mathrm{T}_{7}$ (Table-2). The results of the study revealed that feed intake per $\mathrm{kg}$ egg mass production was significantly $(\mathrm{p}<0.05)$ higher in $\mathrm{T}_{3}(1.0 \%$ sodium-butyrate) as compared to other treatment groups $\left(\mathrm{T}_{1}, \mathrm{~T}_{2}, \mathrm{~T}_{4}, \mathrm{~T}_{5}, \mathrm{~T}_{6}\right.$, and $\left.\mathrm{T}_{7}\right)$ (Table-2).

The results of the present findings are in consonance with the results of Park et al. [26] and Grashorn et al. [19] who observed higher feed efficiency on supplementation of salts of organic acids in the ration of layers. In contrast to these findings, FCR did not differ significantly by supplementation of organic acids in the diet of layers $[15,25]$. It was shown that the efficiency of utilization of feed for egg mass production was significantly improved with the addition of $0.5 \%$ level of salts of organic acids in the diet of laying hens. This improvement in FCR might be due to increase percent hen-day egg production and egg mass production. However, it might be due to the recovery of damaged cells of the digestive wall and preservation of microbial balance and improved nutrient utilization of hens belongs to supplemented groups [20].

\section{Economics of supplementation of salts of organic acids in layers}

Average feed costs (Rs.) per dozen egg production and per $\mathrm{kg}$ egg mass production during progressive weeks of age are given in Table- 4 . These results revealed the possibility of increasing economic efficiency by supplementing the diets with salts of organic acids in laying hens. There was net saving of Rs. 1.74, 1.29, 0.88, 1.57, 0.85 and 0.58 in $\mathrm{T}_{2}, \mathrm{~T}_{3}, \mathrm{~T}_{4}$, $\mathrm{T}_{5}, \mathrm{~T}_{6}$ and $\mathrm{T}_{7}$ groups, respectively, Similarly, there was a reduction in feed cost per $\mathrm{kg}$ egg mass production for Rs. 0.52 and 0.99 in groups $\mathrm{T}_{2}(0.5 \%$ sodium-butyrate) and $\mathrm{T}_{5}(0.5 \%$ calcium-propionate), respectively, in comparison to $\mathrm{T}_{1}$ (control) group. However, there was an increase in feed cost per kg egg mass by Rs. 3.83, 3.33, 2.24 and 3.60 in $\mathrm{T}_{3}, \mathrm{~T}_{4}, \mathrm{~T}_{6}$ and $\mathrm{T}_{7}$ treatment groups, respectively, as compared to $\mathrm{T}_{1}$ (control) group. By contrast to these results, Soltan [23] and Rahman et al. [20] reported that highest economic 


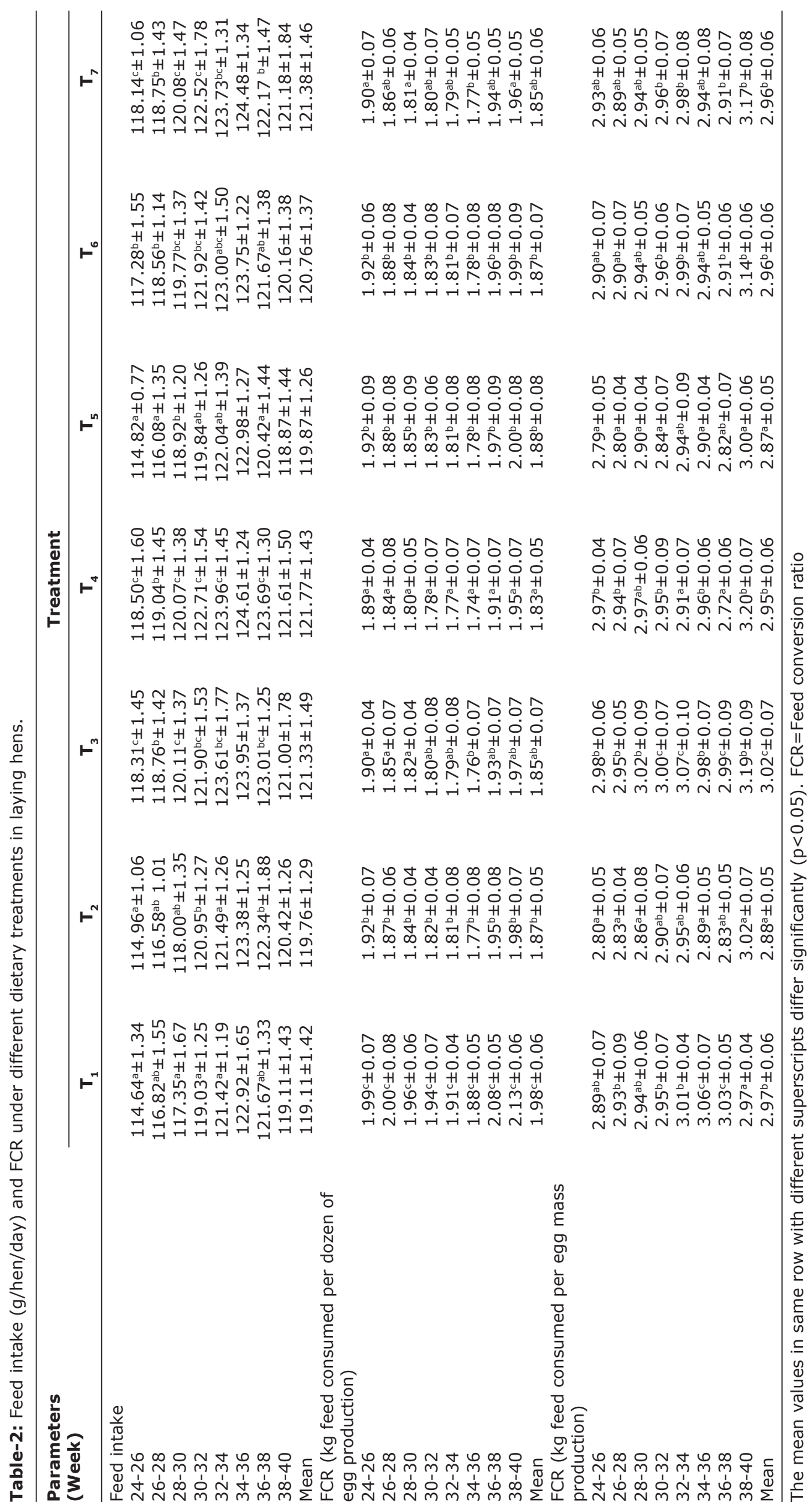


Available at www.veterinaryworld.org/Vol.9/December-2016/24.pdf

Table-3: Egg production and egg weight in layers fed diet supplemented with different levels of probiotics and prebiotics during progressive weeks of age.

\begin{tabular}{|c|c|c|c|c|c|c|c|}
\hline \multirow{2}{*}{$\begin{array}{l}\text { Parameters } \\
\text { (Weeks) }\end{array}$} & \multicolumn{7}{|c|}{ Treatment } \\
\hline & $T_{1}$ & $\mathbf{T}_{2}$ & $\mathbf{T}_{3}$ & $T_{4}$ & $T_{5}$ & $T_{6}$ & $\mathbf{T}_{7}$ \\
\hline \multicolumn{8}{|l|}{$\begin{array}{l}\text { Hen-day egg } \\
\text { production (\%) }\end{array}$} \\
\hline $24-26$ & $72.28^{\mathrm{a}} \pm 0.91$ & $73.53^{\mathrm{ab}} \pm 0.54$ & $74.55^{b c} \pm 0.44$ & $75.86^{\complement} \pm 0.51$ & $73.18^{\mathrm{ab}} \pm 0.97$ & $74.22^{\mathrm{bc}} \pm 0.75$ & $75.19^{c} \pm 0.67$ \\
\hline $26-28$ & $74.09^{a} \pm 0.60$ & $75.62^{\mathrm{ab}} \pm 0.54$ & $76.85^{b} \pm 0.65$ & $78.18^{\wedge} \pm 0.78$ & $75.29^{\mathrm{ab}} \pm 0.52$ & $76.41^{b} \pm 0.52$ & $77.42^{b c} \pm 0.56$ \\
\hline $28-30$ & $75.40^{\mathrm{a}} \pm 0.60$ & $76.80^{\mathrm{b}} \pm 1.19$ & $77.76^{\mathrm{bc}} \pm 1.19$ & $79.25^{\circ} \pm 1.42$ & $76.18^{\mathrm{ab}} \pm 0.64$ & $76.99^{\mathrm{b}} \pm 0.77$ & $78.16^{b c} \pm 1.00$ \\
\hline $30-32$ & $77.16^{\mathrm{a}} \pm 0.60$ & $78.60^{\mathrm{ab}} \pm 1.45$ & $80.07^{b} \pm 1.89$ & $81.58^{\circ} \pm 1.70$ & $77.91^{\mathrm{ab}} \pm 0.62$ & $78.94^{\mathrm{ab}} \pm 0.71$ & $80.30^{\mathrm{b}} \pm 1.27$ \\
\hline $32-34$ & $77.91^{\mathrm{a}} \pm 0.62$ & $78.40^{a} \pm 0.71$ & $80.02^{\mathrm{b}} \pm 1.27$ & $82.33^{c} \pm 1.16$ & $78.15^{\mathrm{a}} \pm 0.66$ & $79.51^{b} \pm 0.89$ & $80.82^{\mathrm{bc}} \pm 1.18$ \\
\hline $34-36$ & $78.85^{\mathrm{a}} \pm 0.67$ & $81.82^{\mathrm{b}} \pm 0.70$ & $83.75^{b c} \pm 0.87$ & $85.63^{c} \pm 0.77$ & $81.30^{b} \pm 0.58$ & $82.42^{\mathrm{ab}} \pm 0.73$ & $83.55^{b c} \pm 0.74$ \\
\hline $36-38$ & $73.71^{a} \pm 0.75$ & $75.63^{\mathrm{ab}} \pm 0.82$ & $76.27^{b} \pm 0.80$ & $79.78^{c} \pm 0.60$ & $75.08^{\mathrm{ab}} \pm 0.82$ & $76.22^{b} \pm 0.88$ & $77.52^{b c} \pm 0.85$ \\
\hline $38-40$ & $68.42^{a} \pm 0.57$ & $68.92^{\mathrm{ab}} \pm 0.48$ & $69.85^{b} \pm 0.44$ & $70.54^{b} \pm 0.47$ & $68.58^{a} \pm 0.41$ & $69.08^{\mathrm{ab}} \pm 0.42$ & $69.42^{\mathrm{ab}} \pm 0.55$ \\
\hline Mean & $74.72^{\mathrm{a}} \pm 0.66$ & $76.16^{b} \pm 0.80$ & $77.39^{`} \pm 0.94$ & $79.14^{\mathrm{d}} \pm 0.92$ & $75.70^{\mathrm{ab}} \pm 0.65$ & $76.72^{\mathrm{bc}} \pm 0.70$ & $77.77^{c} \pm 0.85$ \\
\hline \multicolumn{8}{|l|}{$\begin{array}{l}\text { egg mass } \\
\text { production } \\
\text { (g/day/hen) }\end{array}$} \\
\hline & $.58^{\mathrm{a}} \pm 0.93$ & 41 & $39.64^{\mathrm{a}} \pm 0$. & $39.82^{\mathrm{ab}} \pm 0.84$ & $41.11^{c} \pm 0.55$ & $40.36^{b}$ & $40.27^{b} \pm 0.67$ \\
\hline $26-28$ & $39.86^{a} \pm 0.69$ & $41.15^{c} \pm 0.32$ & $40.15^{\mathrm{ab}} \pm 0.41$ & $40.41^{b} \pm 0.68$ & $41.34^{c} \pm 0.89$ & $40.86^{b c} \pm 0.80$ & $41.07^{c} \pm 0.67$ \\
\hline $28-3$ & $39.90^{\mathrm{a}} \pm 0.51$ & $41.17^{c} \pm 0.94$ & $40.03^{a} \pm 0.93$ & $40.39^{b} \pm 1.22$ & $40.96^{b c} \pm 0.93$ & $40.62^{b} \pm 0.55$ & $40.80^{\mathrm{bc}} \pm 0.75$ \\
\hline $30-32$ & $40.30^{\mathrm{a}} \pm 0.84$ & $41.58^{\mathrm{ab}} \pm 0.94$ & $40.57^{a} \pm 0.94$ & $40.87^{a} \pm 0.95$ & $42.11^{b} \pm 0.62$ & $41.08^{\mathrm{ab}} \pm 0.69$ & $41.36^{\mathrm{ab}} \pm 0.69$ \\
\hline $32-34$ & $40.33^{a} \pm 0.53$ & $41.12^{b} \pm 0.53$ & $40.23^{\mathrm{a}} \pm 1.04$ & $42.53^{c} \pm 0.80$ & $41.50^{b} \pm 0.73$ & $41.12^{b} \pm 0.61$ & $41.43^{b} \pm 0.96$ \\
\hline $34-36$ & $40.07^{a} \pm 0.62$ & $42.38^{c} \pm 0.66$ & $41.58^{b} \pm 0.94$ & $42.07^{c} \pm 0.61$ & $42.36^{c} \pm 0.75$ & $42.05^{\circ} \pm 0.67$ & $42.21^{c} \pm 1.04$ \\
\hline $36-38$ & $40.05^{\mathrm{a}} \pm 0.72$ & $42.73^{c} \pm 0.53$ & $41.01^{\mathrm{ab}} \pm 0.91$ & $42.07^{b} \pm 0.58$ & $42.69^{c} \pm 0.56$ & $41.67^{b} \pm 0.67$ & $41.98^{b} \pm 0.89$ \\
\hline $38-40$ & $38.02^{\mathrm{a}} \pm 0.46$ & $39.51^{b} \pm 0.80$ & $37.91^{\mathrm{a}} \pm 0.84$ & $45.37^{c} \pm 0.46$ & $39.57^{b} \pm 0.77$ & $38.25^{\mathrm{a}} \pm 0.75$ & $38.15^{\mathrm{a}} \pm 0.66$ \\
\hline Mean & $39.76^{a} \pm 0.66$ & $41.32^{c} \pm 0.64$ & $40.14^{\mathrm{ab}} \pm 0.81$ & $41.69^{c} \pm 0.76$ & $41.45^{\complement} \pm 0.72$ & $40.75^{b} \pm 0.70$ & $40.90^{b} \pm 0.79$ \\
\hline $24-26$ & $.77^{b} \pm 0.96$ & $55.68^{c} \pm 0.41$ & $53.18^{\mathrm{ab}} \pm 0.48$ & $52.50^{\mathrm{a}} \pm$ & $56.18^{c} \pm 0.87$ & $54.38^{b} \pm 0.53$ & $53.56^{\mathrm{ab}} \pm$ \\
\hline $26-28$ & $53.81^{b c} \pm 0.61$ & $54.43^{c} \pm 0.44$ & $52.25^{\mathrm{ab}} \pm 0.33$ & $51.69^{\mathrm{a}} \pm 0.93$ & $54.91^{c} \pm 0.44$ & $53.48^{\mathrm{bc}} \pm 0.65$ & $53.05^{b} \pm 0.65$ \\
\hline $28-30$ & $52.93^{b c} \pm 0.59$ & $53.61^{c} \pm 0.68$ & $51.48^{\mathrm{a}} \pm 0.56$ & $50.97^{a} \pm 0.38$ & $53.78^{c} \pm 0.59$ & $52.77^{b c} \pm 0.65$ & $52.21^{b} \pm 0.64$ \\
\hline $30-32$ & $52.24^{b c} \pm 0.83$ & $52.91^{c} \pm 0.75$ & $50.68^{a} \pm 0.43$ & $50.10^{a} \pm 0.70$ & $53.35^{c} \pm 0.93$ & $52.04^{b} \pm 0.90$ & $51.51^{\mathrm{ab}} \pm 0.48$ \\
\hline $32-34$ & $51.77^{\mathrm{ab}} \pm 0.50$ & $52.45^{b} \pm 0.67$ & $50.28^{\mathrm{a}} \pm 1.13$ & $51.67^{\mathrm{ab}} \pm 0.74$ & $53.11^{c} \pm 0.96$ & $51.72^{\mathrm{ab}} \pm 0.60$ & $51.27^{\mathrm{ab}} \pm 0.82$ \\
\hline $34-36$ & $50.83^{\mathrm{ab}} \pm 0.53$ & $51.71^{b c} \pm 0.72$ & $49.65^{\mathrm{a}} \pm 1.17$ & $49.13^{a} \pm 0.73$ & $52.21^{c} \pm 0.86$ & $51.02^{b} \pm 0.63$ & $50.53^{\mathrm{ab}} \pm 0.99$ \\
\hline $36-38$ & $54.34^{\mathrm{ab}} \pm 0.63$ & $56.51^{c} \pm 0.70$ & $53.78^{\mathrm{a}} \pm 1.15$ & $53.30^{a} \pm 0.62$ & $56.87^{c} \pm 0.87$ & $54.68^{b} \pm 0.64$ & $54.16^{\mathrm{ab}} \pm 0.82$ \\
\hline $38-40$ & $55.57^{b} \pm 0.63$ & $57.35^{\complement} \pm 1.01$ & $54.28^{\mathrm{a}} \pm 1.27$ & $53.80^{a} \pm 0.76$ & $57.71^{\complement} \pm 1.07$ & $55.38^{b} \pm 0.71$ & $54.96^{\mathrm{ab}} \pm 0.62$ \\
\hline Mean & $53.28^{b} \pm 0.66$ & $54.33^{c} \pm 0.68$ & $51.94^{a} \pm 0.81$ & $51.64^{a} \pm 0.67$ & $54.76^{c} \pm 0.82$ & $53.19^{b} \pm 0.66$ & $52.65^{\mathrm{ab}} \pm 0.70$ \\
\hline
\end{tabular}

The mean values in same row with different superscripts differ significantly $(p<0.05)$

Table-4: Average feed cost (Rs.) per dozen egg production and per kg egg mass production during progressive age (weeks) under different dietary treatments.

\begin{tabular}{|c|c|c|c|c|c|c|c|}
\hline \multirow[t]{2}{*}{ Parameters (Weeks) } & \multicolumn{7}{|c|}{ Treatment } \\
\hline & $T_{1}$ & $\mathbf{T}_{2}$ & $\mathbf{T}_{3}$ & $\mathbf{T}_{4}$ & $\mathbf{T}_{5}$ & $\mathbf{T}_{6}$ & $\mathbf{T}_{7}$ \\
\hline \multicolumn{8}{|c|}{ Feed cost (Rs.) per dozen egg production } \\
\hline $24-26$ & 44.23 & 43.54 & 44.04 & 44.56 & 43.48 & 44.31 & 44.65 \\
\hline $26-28$ & 44.46 & 42.41 & 42.79 & 43.38 & 42.58 & 43.39 & 43.71 \\
\hline $28-30$ & 43.57 & 41.73 & 42.09 & 42.44 & 41.90 & 42.46 & 42.53 \\
\hline $30-32$ & 43.12 & 41.27 & 41.63 & 41.97 & 41.44 & 42.23 & 42.30 \\
\hline $32-34$ & 42.45 & 41.05 & 41.40 & 41.73 & 40.99 & 41.77 & 42.06 \\
\hline $34-36$ & 41.79 & 40.14 & 40.70 & 41.02 & 40.31 & 41.08 & 41.59 \\
\hline $36-38$ & 46.23 & 44.22 & 44.64 & 45.03 & 44.62 & 45.23 & 45.59 \\
\hline $38-40$ & 47.34 & 44.90 & 45.56 & 45.98 & 45.30 & 45.92 & 46.06 \\
\hline Mean & 44.14 & 42.40 & 42.85 & 43.26 & 42.57 & 43.29 & 43.56 \\
\hline Difference & 0 & -1.74 & -1.29 & -0.88 & -1.57 & -0.85 & -0.58 \\
\hline \multicolumn{8}{|c|}{ Feed cost (Rs.) per kg egg mass production } \\
\hline $24-26$ & 64.24 & 63.50 & 68.92 & 70.03 & 63.19 & 66.93 & 68.85 \\
\hline $26-28$ & 65.13 & 64.18 & 68.23 & 69.32 & 63.42 & 66.93 & 67.91 \\
\hline $28-30$ & 65.35 & 64.86 & 69.85 & 68.38 & 65.68 & 67.85 & 69.09 \\
\hline $30-32$ & 65.57 & 65.77 & 69.39 & 69.56 & 64.32 & 68.31 & 69.56 \\
\hline $32-34$ & 66.91 & 66.90 & 71.00 & 68.61 & 66.59 & 69.00 & 70.03 \\
\hline $34-36$ & 68.02 & 65.54 & 68.92 & 69.79 & 65.68 & 67.85 & 69.09 \\
\hline $36-38$ & 67.35 & 65.18 & 69.15 & 64.13 & 63.87 & 67.16 & 68.38 \\
\hline $38-40$ & 66.02 & 68.49 & 73.78 & 75.45 & 67.95 & 72.47 & 74.49 \\
\hline Mean & 66.07 & 65.55 & 69.90 & 69.40 & 65.08 & 68.31 & 69.67 \\
\hline Difference & 0 & -0.52 & 3.83 & 3.33 & -0.99 & 2.24 & 3.60 \\
\hline
\end{tabular}

The mean values in same row with different superscripts differ significantly $(p<0.05)$ 
efficiency was obtained at higher level (720 ppm) of inclusion of organic acids mixture in the diet of layers.

\section{Conclusions}

From the results of investigation, we can conclude that supplementation of sodium butyrate and calcium propionate was no effect on average feed consumption and body weight gain in layers. Supplementation at $1.5 \%\left(\mathrm{~T}_{4}\right)$ level of sodium butyrate improved percent hen-day egg production, egg mass production and feed intake per dozen eggs, while $0.5 \%\left(\mathrm{~T}_{2}\right)$ level improved egg weight and feed intake per kg egg mass production. In overall, supplementation of sodium butyrate and calcium propionate improved persistency of lay, egg weight, and FCR. The addition of salts of organic acids increased the cost per $\mathrm{kg}$ feed, but the beneficial effects of salts of organic acids as increased hen-day egg production, improved egg mass production and improved FCR leads to decreased feed cost value per dozen egg and per $\mathrm{kg}$ egg mass production at $0.5 \%$ level of inclusion. Supplementation of salts of organic acids had no effect on average feed consumption and body weight gain in layers. Supplementation of salts of organic acids in the diet of layers significantly improved production performance (percent hen-day egg production and egg mass production) and FCRs (feed intake per dozen egg and per kg egg mass). Include that this is a preliminary study and positive and negative control will be included in the future study.

\section{Authors' Contributions}

$\mathrm{RD}$ and RSB have planned the study. RD and CSP recorded the information and analyzed the data. SS, L and CSP provided help in the analysis of data. RSB and CSP drafted and revised the manuscript. All authors read and approved the final manuscript.

\section{Acknowledgments}

The authors are indebted to the Vice Chancellor, Lala Lajpat Rai University of Veterinary and Animal Sciences, Hisar, Haryana, for providing the infrastructure facilities that enabled the successful completion of the project.

\section{Competing Interests} interests.

The authors declare that they have no competing

\section{References}

1. International Poultry and Livestock Expo. (2015) Banglore, India: International Exhibition Centre (BIEC). Available from: http://www.iplexpo.com. Accessed on 07-01-2015.

2. Ratchliff, J. (2000) Antibiotic Ban - A European Perspective. Proceeding of the $47^{\text {th }}$ Maryland Nutrition Conferences for Food Manufacturers. p135-152.

3. EFSA. (2011) Scientific opinion on the safety and efficacy of propionic acid, sodium propionate, calcium propionate and ammonium propionate for all animal species. EFSA J., 9(12): 2446

4. Van Immerseel, F., Russel, J.B., Flythe, M.D., Gantois, I., Timbermont, L., Pasmans, F., Haesebrouck, F. and
Ducatelle, R. (2006) The use of organic acids to combat salmonella in poultry: A mechanism explanation of the efficacy. Avian Pathol., 35: 182-188.

5. Huyghebaert, G., Ducatelle, R. and Van Immerseel, F. (2011) An update on alternatives to antimicrobial growth promoters for broilers. Vet. J., 187: 182-188.

6. Wolfenden, A.D., Vicente, J.L., Higgins, J.P., Andreatti, R.L., Filho, S.E., Higgins, B. and Hargis, M. (2007) Effect of organic acids and probiotics on Salmonella enteritidis infection in broiler chickens. Int. J. Poult. Sci., 6: 403-405.

7. Moharrery, A. and Mahzonieh, M. (2005) Effect of malic acid on visceral characteristics and coliform counts in small intestine in the broiler and layers chickens. Int. J. Poult. Sci., 4(10): 761-764.

8. Nollet, L., Janssens, G. and Arnouts, S. (2004) The use of sodium butyrate (Admix butyrate C) in layer nutrition. Nutri-Ad Int. NV. Available from: http://www.inve.com. Accessed on 03-07-2014.

9. Mahdavi, A.H., Rahmani, H.R. and Pourreza, J. (2005) Effect of probiotic supplements on egg quality and laying hen's performance. Int. J. Poult. Sci., 4: 488-492.

10. BIS. (2007) Requirement for chicken feeds. IS: 13742007, Manak Bhawan, 9 Bahadurshah Zafar Marg, New Delhi - 110001.

11. AOAC. (2007) Official Methods of Analysis. 18 $8^{\text {th }}$ ed. Association of Official Analytical Chemists, Gaithersburg, Madison.

12. SPSS. (2001) Statistical Package for Social Sciences. SPSS Inc., Michigan Avenue, Chicago, IL, USA. p444.

13. Duncan, D.B. (1995) Multiple range and multiple F-test. Biometrics, 11: 1-42.

14. Bonos, E., Christaki, E. and Florou-Paneri, P. (2011) Effects of dietary Mannan-oligosaccharides and Calcium formate on performance and egg quality of Japanese quail. J. Food Sci. Eng., 1(4): 289-296.

15. Kaya, H., Kaya, A., Gul, M. and Celebi, S. (2013) Effect of zeolite and organic acid mixture supplementation in the layer diet on performance, egg quality traits and some blood parameters. J. Anim. Vet. Adv., 12(6): 782-787.

16. Youssef, A.W., Hassan, H.M.A., Ali, H.M. and Mohamed, M.A. (2013) Effect of supplementation of probiotics, probiotics and organic acid on layer performance and egg quality. Asian J. Poult. Sci., 7(2): 65-74.

17. Yesilbag, D. and Colpan, I. (2006) Effects of organic acid supplemented diets on growth performance, egg production, quality and on serum parameters in laying hens. Rev. Med. Vet., 157: 280-284.

18. Tomar, A.K. (2014) Genetic improvement in productivity of egg type chicken through selection. M.V.Sc. Thesis. Lala Lajpat Rai University of Veterinary and Animal Sciences, Hisar.

19. Grashorn, M.A., Gruzauskas, R., Dauksiene, A., Jarule, V., Alencikiene, G. and Slausgalvis, V. (2012) Influence of organic acids on quality and sensory attributes of chicken eggs. Arch. Geflügelk, 77: 29-34.

20. Rahman, M.S., Howlider, M.A.R., Mahiuddin, M. and Rahman, M.M. (2008) Effect of supplementation of organic acid on laying performance, body fat and egg quality of hens. Bangladesh J. Anim. Sci., 37(2): 74-81.

21. Wang, J.P., Yoo, J.S., Lee, J.H., Zhou, T.X., Jang, H.D., Kim, H.J. and Kim, I.H. (2009) Effects of phenyllactic acid on production performance, egg quality parameters and blood characteristics in laying hens. J. Appl. Poult. Res., 18: 203-209.

22. Sari, M., Onol, A.G., Daskiran, M. and Cengiz, O. (2012) Egg production and calcium-phosphorus utilization of laying hens fed diets supplemented with phytase alone or in combination with organic acid. Int. J. Poult. Sci., 11(3): 181-189.

23. Soltan, M.A. (2008) Effect of organic acid supplementation on egg production, egg quality and some blood serum parameters in laying hens. Int. J. Poult. Sci., 7: 613-621. 
24. Attia, Y.A., El-Hamid, A.E., Ellakany, F., Bovera, F., Al-Harthi, M.A. and Ghazaly, S.A. (2013) Growing and laying performance of Japanese quail fed diet supplemented with different concentrations of acetic acid. Ital. J. Anim. Sci., 12: 2.

25. Ozek, K., Wellmann, K.T., Ertekin, B. and Tarum, B. (2011) Effect of dietary herbal essential oil mixture and organic acid preparation on laying traits, gastrointestinal tract characteristics, blood parameters and immune response of laying hens in a hot summer season. J. Anim. Vet. Adv., 20: 575-586.

26. Park, K.W., Rhee, A.R., Um, J.S. and Paik, I.K. (2009) Effect of dietary available phosphorus and organic acids on the performance and egg quality of laying hens. J. Appl. Poult. Res., 18: 598-604.

27. Panda, B., Reddy, V.R., Sadagopan, V.R. and Shrivastav, A.K. (2002). Feeding of poultry. Indian Council of Agricultural Research, New Delhi. Pp 70-79.

$* * * * * * * *$ 